\title{
Non-invasive Analysis of Human Liver Metabolism by Magnetic Resonance Spectroscopy
}

\author{
John G. Jones ${ }^{1 *}$
}

1 CNC - Center for Neuroscience and Cell Biology, CIBB - Centre for Innovative Biomedicine and Biotechnology, University of Coimbra.

* Correspondence: john.griffith.jones@gmail.com; Tel.: +351 231249181

\begin{abstract}
The liver is a key node of whole-body nutrient and fuel metabolism and is also the principal site for detoxification of xenobiotic compounds. As such, hepatic metabolite concentrations and/or turnover rates inform the status of both hepatic and systemic metabolic diseases as well as the disposition of medications. As a tool to better understand liver metabolism in these settings, in vivo magnetic resonance spectroscopy (MRS) offers a non-invasive means of monitoring hepatic metabolic activity in real time both by direct observation of concentrations and dynamics of specific metabolites as well as by observation of their enrichment by stable isotope tracers. This review summarizes the applications and advances in human liver metabolic studies by in vivo MRS over the past 35 years and discusses future directions and opportunities that will be opened by the development of ultra-high field MR systems and by hyperpolarized stable isotope tracers.
\end{abstract}

Keywords: in vivo magnetic resonance; liver metabolism; hyperpolarization; stable isotopes

\section{Introduction}

The liver represents a key metabolic node in the body encompassing nutrient transformation and fuel homeostasis as well as detoxification of ethanol and xenobiotic compounds. Its relatively large size and body location, coupled with a dynamic metabolome that features high concentrations of a diversity of metabolites such as glycogen, glutamine, ATP, sugar phosphates and lipids, has made it an attractive target for in vivo magnetic resonance spectroscopy (MRS) studies of hepatic metabolism since the early days of in vivo MRS development [1-4]. Given that many diseases cause substantial changes in hepatic intermediary metabolism coupled with the availability of higher-field MRS systems for both in vivo human and animal model studies, there is high and ongoing interest in applying this methodology to further our understanding of hepatic intermediary metabolism in physiological and pathophysiological settings. The purpose of this review is to highlight the versatility of multinuclear in vivo MRS both in direct observation of hepatic metabolites as well as hepatic metabolite enrichment from metabolic stable-isotope tracers.

1.1 Observation of hepatic metabolites by MRS: There are several aspects that increase the difficulty of performing in vivo MRS spectroscopy of the liver compared to other large organs such as the brain. These have been previously discussed in detail [5] and can be summarized as follows: First, there is considerable inter-individual variability in its gross structure (i.e. configuration of the lobes and major vessels) hence the region for observation must be carefully tailored for each individual with particular attention to exclude extra-hepatic tissues such as muscle or adipose tissue. Second, in a resting supine individual, the liver position is not static. This is primarily due to diaphragm movement during breathing but other involuntary processes such as intestinal peristalsis and 
pulsatile blood flow also contribute. For this reason, liver MRS data are typically acquired periodically while the subject holds their breath [5-8]. Thirdly, the liver has higher levels of iron compared to many other tissues which results in paramagnetic broadening of MR signals.

1.2 Advances in MRS instrumentation:

Since the development of whole-body MR scanners with fields of 0-5-1.5 $\mathrm{T}$ in the 1980's, there has been a constant push for systems with ever higher magnetic fields. Currently, $3 \mathrm{~T}$ systems are becoming widespread and in 2017, the Food and Drugs Administration approved a $7 \mathrm{~T}$ system as a magnetic resonance imaging device. As of now (2021), the highest operating field for human subjects is $10.5 \mathrm{~T}$ at the University of Minnesota facility, and initial studies indicate that subject safety is not compromised in this setting [9]. There are ongoing efforts to develop systems of 11.7 T (AROMA consortium H2020 grant agreement No 885876) and initiatives for the development of 14-20 T systems [10]. For in vivo MRS spectroscopy, higher magnetic fields deliver an increase in signal dispersion that scales directly with the increase in the applied field $\left(\mathrm{B}_{0}\right)$ while the signal-to-noise ratio (SNR) increases as $\mathrm{B}_{0}{ }^{1.65}$ [11]. At the same time, there is also the need for increased radiofrequency (RF) power deposition that may exceed safety limits. This is primarily an issue for broad-band decoupling of high-gamma nuclei such as ${ }^{1} \mathrm{H}$. In addition, establishing field homogeneity and operating imaging gradients for localized spectroscopy is more challenging at higher fields. Finally, both spin-lattice $\left(\mathrm{T}_{1}\right)$ and transverse relaxation times $\left(\mathrm{T}_{2}\right)$ of many metabolites are sensitive to magnetic field strength [12,13] which can compromise the efficacy of signal collection and alter the relationship between signal intensity and metabolite concentration. To date, there is a strong consensus that the advantages of higher fields far outweigh these drawbacks, particularly for MRS with lowgamma nuclei $[10,11,14]$.

Since high field MRS has been primarily driven by studies on the brain, the integral rf transmit/receive components of high field instruments are optimized for the head rather than the abdominal region. Therefore, liver MRS studies with these systems has required the development of bespoke rf coils and antenna systems [15-17].

1.3 In vivo ${ }^{1} \mathrm{H}$ MRS of liver: $\quad{ }^{1} \mathrm{H}$ is the default observation nucleus for clinical imaging and ${ }^{1} \mathrm{H}$ body coils are also a standard feature for clincal 1.5-3.0 T MR systems. Thus, it is usually feasible to acquire localized ${ }^{1} \mathrm{H}$ spectra of liver tissue on a standard hospital MR scanner.

1.3.1. ${ }^{1} H M R S$ of liver lipids: To date, the most widepread application, and perhaps among the most important in terms of current clinical relevance, is the quantification of liver triglyceride. ${ }^{1} \mathrm{H}$ MRS provides a precise measurement of liver triglyceride levels, with better sensitivity and specificity than other noninvasive probes of liver fat such as ultrasound. This approach was initially validated in a large population (2,349 participants) and established the now widely accepted threshold of $55.56 \mathrm{mg} / \mathrm{g}$ liver triglyceride concentration for non-alcoholic fatty liver disease (NAFLD) based on triglyceride concentrations measured for the $95^{\text {th }}$ percentile of this study cohort [18]. More recently, the detection of the triglyceride signal has been translated into an imaging modality (magnetic resonance imaging-proton density fat fraction, MRI-PDFF) that provides information on the whole liver combined with simpler post-acquisition processing and representation of the data [19]. MRI-PDFF is now considered as the gold standard for hepatic lipid quantification in various settings [20,21]. At fields of $3 \mathrm{~T}$ and above, signals from mono- and polyunsaturated fatty acids become resolved allowing the abundance of these species to be measured thereby providing a lipidomic profile in addition to total liver triglyceride levels [22,23].

1.3.2. ${ }^{1} H$ MRS of other hepatic metabolites: Aside from triglyceride, other hepatic metabolites that have been quantified by ${ }^{1} \mathrm{H}$ MRS include choline and glycogen [24-26] 
which were measured with a $3 \mathrm{~T}$ instrument. While many tumours have high levels of choline, in vivo ${ }^{1} \mathrm{H}$ MRS measurements of hepatic choline in patients with liver tumours did not observe any significant increases in choline compared to healthy subjects [26]. Glycogen observation by conventional in vivo ${ }^{1} \mathrm{H}$ MRS is hampered by several factors including short $\mathrm{T}_{2}$ of its hydrogens and a significant loss of signal during presaturation of the water signal due to saturation transfer [27]. By applying this process in reverse, i.e. pre-saturating the glycogen signals and observing the resulting decrease in the water signal intensity, Zhou et al. were able to follow dynamic changes in hepatic glycogen levels induced by glucagon and fasting re-feeding [28]. Since this approach only requires the quantification of the water signal, it can work at lower fields and can also be translated into an imaging mode.

1.4 In vivo ${ }^{31 P}$ MRS of liver: ${ }^{31} \mathrm{P}$ is the sole stable isotope of phosphorus with a nuclear spin of $1 / 2$ and a relatively strong gyromagnetic ratio $\left(40.5 \%\right.$ that of $\left.{ }^{1} \mathrm{H}\right)$. While the overall chemical shift dispersion for ${ }^{31} \mathrm{P}$ is much greater than that of ${ }^{1} \mathrm{H}(\sim 350$ ppm versus $\sim 10$ ppm), metabolites of phosphorus exists mainly as phosphate mono- or diesters (for example glucose-1-phosphate and fructose 1,6 bisphosphate), phosphoanhydride monoesters with one or two phosphoanhydride bonds, (for example ADP and ATP) and phosphoanhydride diesters with one phosphoanhydride bond, (for example NADH). These signals all resonate within a 25 ppm spectra region, with phosphate mono- and diester species crowded into a $\sim 5$ ppm window. The chemical shift of inorganic phosphate $\left(\mathrm{P}_{\mathrm{i}}\right)$ as well as those of phosphate esters are also sensitive to $\mathrm{pH}[29,30]$ while those of phosphoanhydrides are influenced by the binding of various metal ions such as magnesium [31]. Moreover, saturation transfer experiments allow the transfer of phosphorus from one metabolic intermediate to another to be followed thereby providing information on rates of synthesis such as that of ATP from ADP and $P_{i}$ [32-35]. Thus, in addition to profiling phosphometabolite levels, in vivo ${ }^{31} \mathrm{P}$ MRS informs bioenergetic status and ionic homeostasis. While high resolution ${ }^{31} \mathrm{P}$ NMR of liver extracts can identify over 50 different phospho-metabolites [36], the number of metabolites that can be resolved and quantified by in vivo ${ }^{31} \mathrm{P}$ MRS is far less [37] but is neverthless more diverse in comparison to that provided by ${ }^{1} \mathrm{H}$ MRS. At high magnetic fields $(\geq 7 \mathrm{~T})$, the increased signal dispersion allows more hepatic phospho-metabolites to be resolved and quantified, [38,39] as exemplified by Figure 1 [39]. 

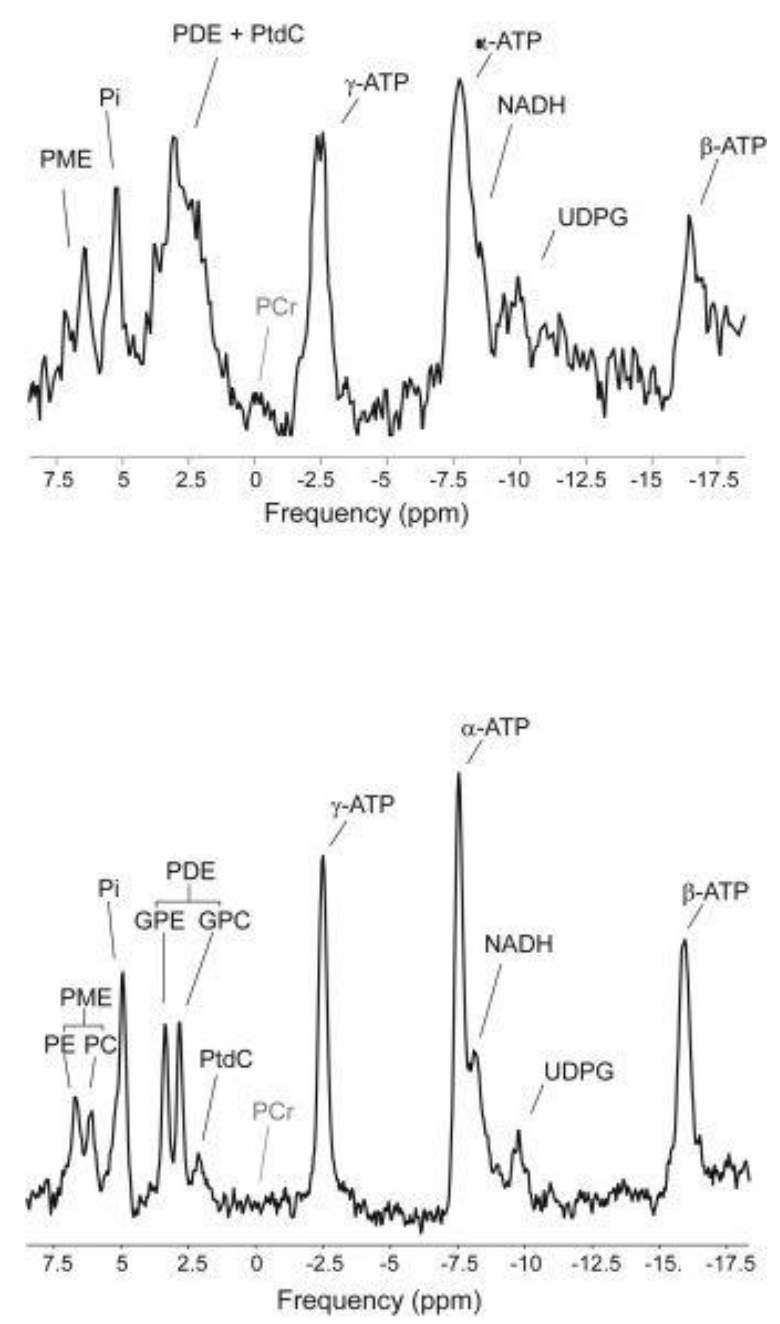

Figure 1: Comparison of in vivo ${ }^{31} \mathrm{P}$ MR spectra of human liver acquired at $3 \mathrm{~T}$ (top) and at $7 \mathrm{~T}$ (bottom). This figure was adapted from ref. [39].

The challenges and potential limiting factors of high-field in vivo ${ }^{31} \mathrm{P}$ NMR MRS include design and implementation of $\mathrm{rf}$ hardware for optimal observation of hepatic metabolites, avoidance of confounding signals from non-hepatic tissues in intimate contact with the liver such as the gall-bladder [40], and maintaining efficient ${ }^{1} \mathrm{H}$-decoupling without exceeding the safe limits for tissue RF power deposition. Finally, there are hepatic studies that integrate the observation of ${ }^{31} \mathrm{P}$ and ${ }^{1} \mathrm{H}$ thereby providing correlated information of phospho-metabolites with other species such as lipids [41-43]. A portfolio of in vivo ${ }^{31} \mathrm{P}$ MRS studies of human liver is shown in Table 1 . This is not meant to include all reported studies to date, but instead to highlight the diversity of topics in hepatic physiology and intermediary metabolism that have been studied. 
Table 1. Selected in vivo ${ }^{31} \mathrm{P}$ MRS studies of liver metabolism in human subjects

\begin{tabular}{|c|c|c|c|}
\hline Study description & Main findings & Field strength $(\mathrm{T})$ & Reference \\
\hline $\begin{array}{c}\text { Effects of a lipid-rich break- } \\
\text { fast meal followed by exer- } \\
\text { cise on hepatic ATP and } \\
\text { lipid levels for healthy } \\
\text { subjects. }\end{array}$ & \begin{tabular}{|} 
Liver fat increased postpran- \\
dially and continued to in- \\
crease during exercise. \\
Liver ATP did not change \\
from fasting to postprandial \\
state, but significantly de- \\
creased after exercise.
\end{tabular} & 3.0 & [43] \\
\hline $\begin{array}{l}\text { Effect of a oral fructose chal- } \\
\text { lenge on hepatic ATP re- } \\
\text { serves in healthy subjects. } \\
\text { Baseline liver glycogen was } \\
\text { also measured by }{ }^{13} \mathrm{C} \text { NMR }\end{array}$ & $\begin{array}{c}\text { Hepatic ATP levels dropped } \\
\text { by } \sim 20 \% \text { from baseline and } \\
\text { reached a minimum value } 50 \\
\text { minutes after the load. The } \\
\text { time to reach minimum ATP } \\
\text { levels was inversely corre- } \\
\text { lated with subject BMI. ATP } \\
\text { recovery rate was inversely } \\
\text { correlated with baseline gly- } \\
\text { cogen levels. }\end{array}$ & 3.0 & {$[44]$} \\
\hline $\begin{array}{l}\text { Effects of acute fructose in- } \\
\text { gestion with and without an } \\
\text { accompanying load of etha- } \\
\text { nol on liver P-metabolite dy- } \\
\text { namics in healthy subjects. }\end{array}$ & $\begin{array}{l}\text { Over a } 40 \text { minute interval } \\
\text { post load, P-metabolites } \\
\text { were measured with } 5 \text { mi- } \\
\text { nute time resolution. While } \\
\text { ethanol had no effects on } \\
\text { rates of phosphomonester } \\
\text { (PME) formation and ATP } \\
\text { depletion resulting from } \\
\text { fructose metabolism, it sig- } \\
\text { nificantly slowed down the } \\
\text { rate of PME degradation. } \\
\end{array}$ & 1.5 & [45] \\
\hline $\begin{array}{l}\text { Characterization of P-metab- } \\
\text { olites and ATP fluxes and } \\
\text { correlation with lipid levels } \\
\text { determined by }{ }^{1} \mathrm{H} \text { MR and } \\
\text { biopsy evaluation in subjects } \\
\text { with NAFLD and NASH }\end{array}$ & $\begin{array}{l}\text { Several PME and PDE }{ }^{31} \mathrm{P} \\
\text { signals were resolved and } \\
\text { quantified as well as those } \\
\text { from NADPH and UDPG. } \\
\text { Significant differences in rel- } \\
\text { ative abundances of PME } \\
\text { phosphoethanolamine (PE) } \\
\text { and ATP between NAFLD } \\
\text { and NASH. Significantly } \\
\text { lower rates of ATP synthesis } \\
\text { fluxes in NASH compared to } \\
\text { NAFLD subjects. }\end{array}$ & $\begin{array}{l}7.0\left({ }^{31} \mathrm{P}\right) \\
3.0\left({ }^{1} \mathrm{H}\right)\end{array}$ & [32] \\
\hline $\begin{array}{l}\text { Characterization of PME pro- } \\
\text { file in fasted subjects with } \\
\text { compensated and decompen- } \\
\text { sated cirrhosis following in- } \\
\text { fusion with a gluconeogenic } \\
\text { substrate - L-alanine. }\end{array}$ & $\begin{array}{l}\text { At baseline, PME levels of } \\
\text { both compensated and de- } \\
\text { compensated cirrhotic sub- } \\
\text { ects were elevated compared } \\
\text { to healthy controls. After L- } \\
\text { alanine infusion, PME levels } \\
\text { of healthy controls were sig- } \\
\text { nificantly increased, con- } \\
\text { sistent with gluconeogenic }\end{array}$ & 1.5 & [46] \\
\hline
\end{tabular}




\begin{tabular}{|l|l|l|l|}
\hline & $\begin{array}{l}\text { activity. This increase was } \\
\text { significantly smaller for pa- } \\
\text { tients with compensated cir- } \\
\text { rhosis and was absent in pa- } \\
\text { tients with decompensated } \\
\text { cirrhosis. }\end{array}$ & & \\
\hline $\begin{array}{l}\text { Characterization of P-metab- } \\
\text { olites in pediatric liver trans- } \\
\text { plant patients with different } \\
\text { outcomes of graft function }\end{array}$ & $\begin{array}{l}\text { Patients with impaired graft } \\
\text { PME/total phosphate com- } \\
\text { pared to those with good } \\
\text { graft function and to healthy } \\
\text { controls. }\end{array}$ & & [47] \\
\hline $\begin{array}{l}\text { Eiver ATP levels were signif- } \\
\text { icantly increased following } \\
\text { infusion for 22-24 hours on } \\
\text { liver energy status in ad- } \\
\text { vanced lung cancer patients. }\end{array}$ & $\begin{array}{l}\text { ATP infusion to levels that } \\
\text { were similar to those of } \\
\text { healthy subjects. This effect } \\
\text { was greatest for patients that } \\
\text { were undergoing weight loss } \\
\text { and who had the lowest } \\
\text { baseline ATP liver levels }\end{array}$ & & \\
\hline
\end{tabular}

1.5 In vivo ${ }^{13} \mathrm{C}$ MRS of liver: ${ }^{13} \mathrm{C}$ is the stable isotope of carbon with a spin of $1 / 2$ and a natural abundance of $1.1 \%$. Its gyromagnetic ratio is $\sim 1 / 4$ that of ${ }^{1} \mathrm{H}$ hence its overall sensitivity is several orders of magnitude less than that of ${ }^{1} \mathrm{H}$. Nevertheless, for liver metabolites that can reach high concentrations, such as glycogen and lipids, their natural abundance ${ }^{13} \mathrm{C}$ signals can be observed with reasonable collection times [2,3,49]. In addition, ${ }^{13} \mathrm{C}$ signals from isotopically enriched substrates and their metabolic products, where ${ }^{13} \mathrm{C}$ abundance can be boosted to nearly 100 -fold over background levels, can be detected [50-54].

The ${ }^{13} \mathrm{C}$ chemical shift dispersion is much greater in comparison to ${ }^{1} \mathrm{H}$, therefore in principle it provides increased resolution of metabolites. On the other hand, the majority of metabolite carbons are bound to one or more hydrogens that result in the ${ }^{13} \mathrm{C}$ signal being split by ${ }^{1} \mathrm{H}-{ }^{13} \mathrm{C}$ scalar coupling. Not only does this effectively reduce the signal-tonoise ratio by at least a factor of 4 , it also duplicates the number of metabolite signals within the same spectral region thereby compromising signal resolution. These effects can be eliminated by broadband ${ }^{1} \mathrm{H}$-decoupling which also provides an additional boost to the ${ }^{1} \mathrm{H}$-decopuled ${ }^{13} \mathrm{C}$ singlet signal by the nuclear Overhauser enhancement (nOe) effect. As magnetic fields increase, the ${ }^{1} \mathrm{H}$-frequency decoupling bandwidth also needs to be increased resulting in higher deposition of rf power into tissues. Moreover, nOe can vary substantially between ${ }^{13} \mathrm{C}$ in different molecular sites, and this must be taken into account when relating ${ }^{13} \mathrm{C}$ signal intensities to absolute metabolite concentrations. Finally, the $T_{1}$ of non-protonated carbons such as carboxyls and quaternary carbons are relatively long, which in combination with an absence of nOe, can constrain the acquisition of their ${ }^{13} \mathrm{C}$ signals over short intervals. In vivo ${ }^{13} \mathrm{C}$ MR of hepatic metabolism in humans is being driven forward by several innovations that directly confront the limitations described earlier. To minimize the deposition of rf power into the region of observation as a result of broadband ${ }^{1} \mathrm{H}$ decoupling, bespoke decoupling schemes have been developed [55]. For 
studies that focus on observation of a single metabolite ${ }^{13} \mathrm{C}$ signal, such as the carbon 1 resonance of glycogen, it is only necessary to decouple the hydrogen attached to this carbon, hence the decoupling bandwidth - and therefore the power deposition - can be substantially reduced. This approach was used in the one of the pioneering in vivo ${ }^{13} \mathrm{C} \mathrm{MR}$ studies of liver metabolism, which documented the decrease in the natural-abundance ${ }^{13} \mathrm{C} 1$ signal of liver glycogen during fasting in healthy humans [56]. In some cases, ${ }^{13} \mathrm{C}-$ signals of ${ }^{13} \mathrm{C}$-enriched hepatic metabolites can be resolved and quantified in the absence of ${ }^{1} \mathrm{H}$-decoupling. For example, the appearance of ingested $\left[1-{ }^{13} \mathrm{C}\right]$ glucose in the liver and its conversion to $\left[1-{ }^{13} \mathrm{C}\right]$ glycogen was observed at $3 \mathrm{~T}$ with 0.5 minute time resolution without deployment of ${ }^{1} \mathrm{H}$ decoupling [50].

The interaction of ${ }^{13} \mathrm{C}$ and ${ }^{1} \mathrm{H}$ via scalar coupling provides the basis for monitoring ${ }^{13} \mathrm{C}$-enrichment indirectly via observation of the attached proton(s). While ${ }^{1} \mathrm{H}$ observation delivers vastly increased signal sensitivity and is also the default nucleus for in vivo localized spectroscopy with whole-body MR systems, the pulse sequences for selecting the ${ }^{1} \mathrm{H}$ ${ }^{13} \mathrm{C}$-coupled signals while filtering out those from ${ }^{1} \mathrm{H}-{ }^{12} \mathrm{C}$ are more complex and require precise calibration of the rf electronics. Although in principle, the ${ }^{1} \mathrm{H}-{ }^{13} \mathrm{C}$-coupled signals can be resolved along both ${ }^{1} \mathrm{H}$ and ${ }^{13} \mathrm{C}$ dimensions, for in vivo studies, time and instrument constraints limit the signal acquisition to the ${ }^{1} \mathrm{H}$ dimension only. Thus, the signal dispersion is limited to that of ${ }^{1} \mathrm{H}$, which effectively precludes shotgun observation of arrays of ${ }^{13} \mathrm{C}$-enriched metabolites but may nevertheless be effective for observation of a single ${ }^{13} \mathrm{C}$ enriched species. Veeraiah et al. developed a pulse sequence protocol that allowed the ${ }^{13} \mathrm{C}$-enriched methylene signals of hepatic fatty acids to be observed in the liver of healthy subjects via ${ }^{1} \mathrm{H} \mathrm{MR}$ with high sensitivity and minimal interference from ${ }^{1} \mathrm{H}-{ }^{12} \mathrm{C}$ signals [57].

The advent of hyperpolarization (HP), which can boost the difference in nuclear spin populations between the two spin states of the ${ }^{13} \mathrm{C}$ nucleus by several orders of magnitude over that achieved by an applied magnetic field, provides correspondingly huge gains in sensitivity for observation of ${ }^{13} \mathrm{C}$-enriched substrates. However, this advantage can only be realized over a relatively limited time window that is ultimately constrained by the longitudinal relaxation time $\left(\mathrm{T}_{1}\right)$ of the observed ${ }^{13} \mathrm{C}$ species. Since the longest $\mathrm{T}_{1}$ values for ${ }^{13} \mathrm{C}$-enriched substrates rarely exceed 60 seconds, with $99 \%$ of the nuclear magnetization lost over an interval of $5 \times \mathrm{T}_{1}$, the challenges in rapid administration and in vivo observation of hyperpolarized ${ }^{13} \mathrm{C}$-enriched substrates are reminiscent of those encountered in positron emission tomography (PET) studies of short-lived nuclei such as ${ }^{13} \mathrm{~N}$ and ${ }^{11} \mathrm{C}$. To date, HP studies of liver metabolism with ${ }^{13} \mathrm{C}$-enriched substrates have been limited to preclinical animal models. The principal obstacles in translation of this approach to humans have been in ensuring the safety and enabling rapid delivery of hyperpolarized ${ }^{13} \mathrm{C}$ enriched substrates. Both $\left[1-{ }^{13} \mathrm{C}\right]-$ and $\left[2-{ }^{13} \mathrm{C}\right]$ pyruvate have obtained regulatory approval by the FDA as substrates for hyperpolarized MRI [58]. In a study of patients with prostate cancer, delivery of hyperpolarized [1-13C]pyruvate was not associated with any adverse events [59]. Given the diversity of pre-clinical studies of HP ${ }^{13} \mathrm{C}$-enriched substrates in both perfused liver as well as in vivo, it is quite certain that this methodology will be applied to the study of human liver metabolism in the very near future.

\subsection{In vivo MRS of other nuclei in the study of hepatic metabolism:}

1.6.1: Deuterium: Deuterium $\left({ }^{2} \mathrm{H}\right)$ is a quadrupolar nucleus with a spin of 1 and a gyromagnetic ratio that is $\sim 15 \%$ that of ${ }^{1} \mathrm{H}$. Its natural abundance is $0.015 \%$, which alongside its limited dispersion $\left(15 \%\right.$ that of $\left.{ }^{1} \mathrm{H}\right)$ makes it a poor choice for observation of liver metabolites compared to ${ }^{31} \mathrm{P}$ or natural abundance ${ }^{13} \mathrm{C} \mathrm{MRS}$. However, its low natural abundance also means that ${ }^{2} \mathrm{H}$-enriched substrates, which are up to $\sim 2000$ times higher than the background, can be more effectively observed. In addition, ${ }^{2} \mathrm{H} \mathrm{T}_{1}$ values are much shorter compared to those of ${ }^{1} \mathrm{H},{ }^{13} \mathrm{C}$, or ${ }^{31} \mathrm{P}$ allowing more free-induction decays 
to be collected per unit time thereby effectively boosting sensitivity. However, for large molecular weight metabolites such as glycogen that exhibit very short spin-spin $\left(\mathrm{T}_{2}\right)$ relaxation times, $\mathrm{MR}$ visibility of the ${ }^{2} \mathrm{H}$ label may be severly compromised [60]. Since the coupling constants of ${ }^{2} \mathrm{H}$ with neighboring ${ }^{1} \mathrm{H}$ nuclei are relatively small, ${ }^{2} \mathrm{H}$ signals are not substantially degraded by these interactions and can therefore be observed in the absence of broadband ${ }^{1} \mathrm{H}$ decoupling. In terms of MR hardware, magnetic field strength is the most important limiting factor in the development of metabolic studies with ${ }^{2} \mathrm{H}$ enriched tracers. De Feyter et al. obtained in vivo ${ }^{2} \mathrm{H} \mathrm{MR}$ signals at a field of $4 \mathrm{~T}$ from human liver following ingestion of a glucose load enriched with [6,6-2 $\mathrm{H}_{2}$ ]glucose [61]. Under these conditions, there was no resolution of $\left[6,6-2 \mathrm{H}_{2}\right]$ glucose and $\left[6,6-2 \mathrm{H}_{2}\right]$ glycogen signals, but given that $\left[6,6-{ }^{2} \mathrm{H}_{2}\right]$ glycogen was likely not visible under the parameters used for observation, the signals were likely those of $\left[6,6-{ }^{2} \mathrm{H}_{2}\right]$ glucose.

In cases where the ${ }^{2} \mathrm{H}$ label can undergo exchange with ${ }^{1} \mathrm{H}$, for example during conversion of $\left[6,6-{ }^{2} \mathrm{H}_{2}\right]$ glucose to $\left[3,3-{ }^{2} \mathrm{H}_{2}\right]$ lactate, where the $\left[3,3-{ }^{-2} \mathrm{H}_{2}\right]$ pyruvate intermediate can exchange its ${ }^{2} \mathrm{H}$ with ${ }^{1} \mathrm{H}$ body water, the product signal intensity needs to be corrected for this exchange. Also, for ${ }^{2} \mathrm{H}$-enriched substrates whose metabolism involves the cleavage of a ${ }^{2} \mathrm{H}-{ }^{13} \mathrm{C}$-bond, for example conversion of $\left[2-{ }^{2} \mathrm{H}\right]$ glucose-6-P to fructose-6-P via glucose-6-P isomerase [62] the presence of a significant kinetic isotope effect may substantially alter the rate of tracer metabolism relative to its tracee.

The study of liver metabolism can also be undertaken with deuterated water $\left({ }^{2} \mathrm{H}_{2} \mathrm{O}\right)$. ${ }^{2} \mathrm{H}_{2} \mathrm{O}$ is inexpensive and can be safely administered to $0.5 \%$ body water in humans ( 33 times above background) over an indefinite period. The ubiquity of water and metabolite hydrogen exchanges in intermediary metabolic pathways results in the ${ }^{2} \mathrm{H}$ enrichment of a diversity of metabolites including lipids and amino acids. Among other things, the rate of ${ }^{2} \mathrm{H}$ enrichment of a given metabolite informs its rate of synthesis and/or turnover. With the advent of very high fields $(>10 \mathrm{~T})$, it is likely that hepatic ${ }^{2} \mathrm{H}$ signals of metabolites enriched by ${ }^{2} \mathrm{H}_{2} \mathrm{O}$ will be at least partially resolved in vivo for human subjects.

1.6.2 Fluorine: As for ${ }^{31} \mathrm{P}$, fluorine exists in nature as single stable isotope, ${ }^{19} \mathrm{~F}$. It has a spin of $1 / 2$, and its sensitivity is $83 \%$ that of ${ }^{1} \mathrm{H}$. It generates sharp NMR signals that cover a wide chemical shift range. Its relaxation properties are similar to that of ${ }^{1} \mathrm{H}$, hence conventional ${ }^{1} \mathrm{H}$ pulse sequences for quantitative measurement of ${ }^{1} \mathrm{H}$ metabolite signals can be easily adapted for ${ }^{19} \mathrm{~F}$. An adult human has $2.6 \mathrm{~g}$ of fluorine that it is almost entirely distributed as fluoride in teeth and bone. Thus, soft biological tissues have essentially no background ${ }^{19} \mathrm{~F}$ signal, therefore suppression of superfluous signals is not required and spectrometer sensitivity can be fully exploited.

Essentially all in vivo human studies involving ${ }^{19} \mathrm{~F}$ have focused on the appearance and/or metabolism of pharmacological agents containing ${ }^{19} \mathrm{~F}$ as part of their molecular composition. The first report describing the observation of hepatic ${ }^{19} \mathrm{~F}$ signals in vivo was published by Wolf et al in 1987 [63]. Three cancer patients were studied with a $1.5 \mathrm{~T}$ system following ingestion of the anti-cancer drug 5-fluoro uracil (5-FU). Subsequently, the kinetics of 5-FU appearance in the liver and its bio-transformation to 5-fluoro ureido propionic acid and $\alpha$-fluoro- $\beta$-alanine were documented [64-68]. It was demonstrated that 5 -FU was retained longer by tumour tissue compared to the surrounding healthy tissues [64] and that tumour 5-FU levels were positively correlated with the clinical response to treatment $[67,69]$. In vivo ${ }^{19} \mathrm{~F}$ MR studies demonstrated that the lifetime of 5-FU within hepatic tumours could be extended by interferon- $\alpha$ [70] and by inhibitors of 5-FU catabolism [71]. In a study performed at $3 \mathrm{~T}$, where different regions of the liver were assayed following ingestion of Capecitabine, a pro-drug that is metabolized to 5-FU via 5 '-deoxyfluorocytidine 5 '-deoxyfluorouridine, these intermediates as well as products of 5 -FU degradation such $\alpha$-fluoro- $\beta$-alanine and 5-fluoro ureido propionic acid were detected and quantified. These metabolites were found to be heterogenously distributed in the liver [72]. 
Sitafloxacin is a broad-spectrum antibacterial agent that contains a fluorine atom in its chemical structure. Its appearance and washout in the lever was characterized in a group of healthy subjects with a $1.5 \mathrm{~T}$ system [73]. These parameters were found to be similar to that measured in plasma using HPLC indicating that this drug was not retained in the liver for any significant time [73]. Niflumic acid is a medication for alleviating pain in muscle and joints and has a trifluoromethyl functional group as part of its structure. A study of healthy male volunteers who ingested a single dose of Niflumic acid was performed at $1.59 \mathrm{~T}$ [74]. In addition to the appearance of a ${ }^{19} \mathrm{~F}$ signal corresonding to niflumic acid, a second signal was observed and was identified as 4 ' -hydroxy niflumic acid (4-HNA). The washout kinetics of the secondary metabolite was much slower in comparison to that of niflumic acid, and was attributed to the fact that while the parent drug is rapidly cleared via blood and urine, 4-HNA is cleared via the biliary system. To the extent that 4-HNA is recirculated via enterohepatic biliary circulation, its net clearance from the region of observation is slowed down. The authors also acknowledged that the 4-HNA signal might at least in part be originating from the biliary system itself rather than from liver tissue.

\section{7: Future perspectives:}

The two key drivers for the advancement of in vivo MR studies of human liver metabolism are the development of ultra high field clinical MR systems $(\geq 7.0 \mathrm{~T})$ and the availability of hyperpolarized stable-isotope tracers. While each of these technical developments by themselves will undoubtedly advance the state-of-the-art, there is a high degree of synergy when both are combined. This is well illustrated by preclinical studies that have integrated hyperpolarized tracers with in vivo MR observation at mid- to high fields. Table 2 shows some selected examples and their potential to advanced our knowledge of liver metabolism in the clincal setting.

Table 2. Pre-clinical studies of liver metabolism utilizing hyperpolarized tracers and mid-to high field MR systems..

\begin{tabular}{|c|c|c|c|}
\hline Study description & $\begin{array}{l}\text { Impact on advancing our under- } \\
\text { standing of liver metabolism }\end{array}$ & $\begin{array}{c}\text { Field } \\
\text { strength }(\mathrm{T})\end{array}$ & Reference \\
\hline $\begin{array}{c}\text { Metabolic fate of hyperpolarized [1- } \\
{ }^{13} \text { C]pyruvate in perfused mouse liv- } \\
\text { ers. }\end{array}$ & $\begin{array}{c}\text { In situ detection of Krebs cycle metab- } \\
\text { olites and amino acids from anaple- } \\
\text { rotic metabolism of pyruvate. }\end{array}$ & 9.4 & [75] \\
\hline $\begin{array}{c}\text { Hepatic metabolism of hyperpolar- } \\
\text { ized }\left[2-{ }^{13} \mathrm{C}\right] \text { dihydroxyacetone by } \\
\text { mice in situ and in isolated perfused } \\
\text { livers. }\end{array}$ & $\begin{array}{c}\text { Real time observation of hepatic glu- } \\
\text { coneogenic and glyceroneogenic inter- } \\
\text { mediates. }\end{array}$ & $7.0 ; 9.4 ; 14.1$ & [76-78] \\
\hline $\begin{array}{c}\text { Hepatic metabolism of hyperpolar- } \\
\text { ized }\left[1-{ }^{13} \mathrm{C}\right] \text { lactate in rats }\end{array}$ & $\begin{array}{c}\text { In vivo assessment of hepatic pyruvate } \\
\text { carboxylase activity. }\end{array}$ & 3.0 & [79] \\
\hline $\begin{array}{c}\text { Metabolism of }\left[1-{ }^{13} \mathrm{C}\right] \text { gluconolactone } \\
\text { in perfused mouse livers }\end{array}$ & $\begin{array}{c}\text { Probe for assessing hepatic pentose } \\
\text { phosphate pathway activity }\end{array}$ & 9.4 & {$[80]$} \\
\hline $\begin{array}{c}\text { Hepatic metabolism of hyperpolar- } \\
\text { ized }[1-13 \mathrm{C}] \text { pyruvate in mice under- } \\
\text { going hyperinsulinemic-euglycemic } \\
\text { clamp. }\end{array}$ & $\begin{array}{l}\text { In vivo assessment on the effects of in- } \\
\text { sulin on hepatic pyruvate metabolism. }\end{array}$ & 9.4 & {$[81]$} \\
\hline $\begin{array}{l}\text { Comparison of hyperpolarized [1- } \\
{ }^{13} \text { C]alanine metabolism in rat models } \\
\text { of Type } 1 \text { and Type } 2 \text { diabetes }\end{array}$ & $\begin{array}{c}{\left[1-{ }^{13} \mathrm{C}\right] \text { alanine had distinctive meta- }} \\
\text { bolic fates in the livers from the Type } \\
1 \text { versus the Type } 2 \text {-diabetes model }\end{array}$ & 3.0 & {$[82]$} \\
\hline $\begin{array}{l}\text { Administration of hyperpolarized } \\
{ }^{13} \text { C-enriched ethyl acetyl carbonate } \\
\text { for in situ generation and MR }\end{array}$ & In vivo $\mathrm{pH}$ imaging of liver tissue. & 4.7 & {$[83]$} \\
\hline
\end{tabular}




\begin{tabular}{|c|c|c|c|}
\hline $\begin{array}{l}\text { detection of hyperpolarized }{ }^{13} \mathrm{C} \text {-bi- } \\
\text { carbonate and }{ }^{13} \mathrm{CO}_{2} \\
\end{array}$ & & & \\
\hline \begin{tabular}{|c|} 
Administration of hyperpolarized \\
${ }^{13}$ C-enriched thiourea, a probe for re- \\
active oxygen species. \\
\end{tabular} & $\begin{array}{l}\text { Detection of } i n \text { situ hydrogen peroxide } \\
\text { production in liver. }\end{array}$ & 3.0 & [84] \\
\hline $\begin{array}{c}\text { Administration of hyperpolarized [1- } \\
\left.{ }^{13} \mathrm{C}\right] \text { alanine and analysis of }\left[1-{ }^{-13} \mathrm{C}\right] \mathrm{lac}- \\
\text { tate and }\left[1-{ }^{-13} \mathrm{C}\right] \text { pyruvate products in } \\
\text { rat liver. }\end{array}$ & Assessment of hepatic redox state. & 3.0 & [85] \\
\hline $\begin{array}{c}\begin{array}{c}\text { Administration of hyperpolarized } \\
{ }^{15} \mathrm{~N} \text {-carnitine and in situ observation } \\
\text { of its }{ }^{15} \mathrm{~N} \text { signal in rat liver. }\end{array} \\
\end{array}$ & \begin{tabular}{|c|}
$\begin{array}{c}\text { Carnitine is a key cofactor in the mito- } \\
\text { chondrial oxidation of long-chain } \\
\text { fatty acids. }\end{array}$ \\
\end{tabular} & 4.7 & [86] \\
\hline $\begin{array}{c}\text { Adminstration of hyperpolarized } \\
\text { ethyl }\left[1,3-{ }^{13} C_{2}\right] \text { acetoacetate to rats } \\
\text { with hepatic tumors }\end{array}$ & \begin{tabular}{|c|} 
Increased appearance of ethyl [1,3- \\
$\left.{ }^{13} \mathrm{C}_{2}\right]$ acetoacetate in the tumor com- \\
pared to healthy tissue related to met- \\
abolic heterogeneity between tumor \\
and hepatocytes
\end{tabular} & 3.0 & [87] \\
\hline \begin{tabular}{|c|} 
Characterization of hyperpolarized \\
{$\left[1-^{-13} \mathrm{C}\right]$ pyruvate metabolism in a rat } \\
model of latent, treatment-refractory \\
liver tumor cells.
\end{tabular} & \begin{tabular}{|c|}
$\begin{array}{c}\text { Latent tumor cells generated an iden- } \\
\text { tifiable metabolic profile, reflecting } \\
\text { metabolic programming for survival } \\
\text { of therapeutic intervention. }\end{array}$ \\
\end{tabular} & 9.4 & [88] \\
\hline
\end{tabular}

One of the key roles of the liver is the regulation of endogenous glucose production and the control of gluconeogenic flux is a key component of this process. Current methodologies rely on measuring the appearance of a gluconeogenic tracer in plasma glucose. For various technical and theoretical reasons, this measurement is limited to quasi steady-state conditions, such as after overnight fasting or during a glucose clamp. Thus, the transition from fasting to feeding, where hepatic carbohydrate metabolic fluxes must undergo acute rearrangements in order to maintain whole body glucose homeostasis - and is therefore the most critical and testing phase for glucoregulation - is little understood. The ability to observe fast real-time alterations in hepatic sugar phosphates and other metabolites following administration of tracers such as $\left[2-{ }^{13} \mathrm{C}\right]$ dihydroxyacetone [76-78], [1-13 C]pyruvate [75], [79], [81], and [1- $\left.{ }^{13} \mathrm{C}\right]$ gluconolactone [80] promises to be invaluable for unveiling the redirection of hepatic carbohydrate fluxes during the fasted to fed transition. Moreover, the direct observation of hepatic metabolites overcomes another important limitation of gluconeogenic tracer enrichment of blood glucose: the inability to resolve gluconeogenic activity of the liver from that of other tissues such as the kidney and intestine.

For chronic metabolic diseases such as NAFLD and T2D, there is now renewed focus on the function of hepatocyte mitochondria in these settings. The leakage of electrons from complexes I and III of the electron transport chain results in the generation of reactive oxygen species (ROS). In addition to damaging critical cellular infrastructure such as membrane lipids and DNA, ROS also promote inflammation and can trigger cellular apoptosis and autophagy. Thus, the development of noninvasive hepatic ROS probes such as hyperploarized thiourea [84] and markers of hepatic redox state such as [1${ }^{13} \mathrm{C}$ ]alanine and $\left[1-{ }^{13} \mathrm{C}\right]$ lactate [85] will provide a deeper insight on the role and status of hepatic ROS in various physiological and pathophysiological settings. The oxidation of long-chain fatty acids (LCFA) by hepatocyte mitochondria is a critical component in hepatic lipid homeostasis and ketone body generation and is highly controlled by LCFA uptake via the carnitine shuttle. Defects in hepatic mitochondrial fatty acid oxidation are associated with increased levels of acylcarnitine intermediates [89-91] hence the development of probes for assessing hepatic carnitine metabolism, such as hyperpolarized ${ }^{15} \mathrm{~N}$-carnitine [86] can potentially inform the status of hepatic LCFA 
oxidation. Finally, oxidative and anaplerotic pyruvate metabolism - mediated by mitochondrial pyruvate dehydrogenase and pyruvate carboxylase, respectively - is a key node in the hepatic metabolic network. Among other things, it commits pyruvate to either a gluconeogenic or lipogenic fate. The metabolic path of hyperpolarized [1${ }^{13}$ C]pyruvate can be followed in real time [75] thus providing the potential for a deeper understanding on the role of this critical metabolic conrol point in various nutritional and disease settings $[79,81,82]$.

After lung cancer, hepatocellular cancer (HCC) is the leading cause of cancer deaths in the world [92] with NAFLD being the most rapidly growing contributor to HCC mortality and morbidity [93]. Noninvasive in situ metabolic profiling of liver tumours will deepen our understanding of tumour physiology and response to therapy and preclincal proof-of-concept studies of hepatic tumours with hyperpolarized substrates are poised to be translated into the clincal setting. The selective uptake and retention of hyperpolarized ethyl $\left[1,3-{ }^{13} \mathrm{C}_{2}\right.$ ]acetoacetate by tumour tissue over healthy hepatocytes [87] provides the basis for tumour metabolic contrast agent imaging and also reveals important differences in carboxyl esterase activities between tumours and healthy tissue that may be exploited for pharmacological targeting. Imaging of tissue $\mathrm{pH}$ from hyperpolarized ${ }^{13} \mathrm{CO}_{2}$ and bicarbonate delivered in the form of hyperpolarized ethyl acetyl carbonate [83] can potentially delineate tumour necrotic regions which are typically hypoxic and acidic and also increase resistance to therapy. Finally, the local recurrence of HCC following therapy is a frequent and ominous event. Thus, improving our understanding of how tumour cells resist therapy and detection of surviving latent tumour cells is of critical importance in achieving better outcomes. By identifying a characteristic metabolic profile for latent tumour cells via hyperpolarized $\left[1-{ }^{13} \mathrm{C}\right]$ pyruvate that provides the basis for their metabolic imaging, Perkons et al. also demonstrated that metabolic reprogramming is a key component of tumour cell survival [88].

Funding: This work was financed by the European Regional Development Fund (ERDF), through the Centro 2020 Regional Operational Programme through the COMPETE 2020 - Operational Programme for Competitiveness and Internationalisation and Portuguese national funds via FCT Fundação para a Ciência e a Tecnologia, under projects POCI-01-0145-FEDER-028147, UIDB/04539/2020 and UIDP/04539/2020.

Conflicts of Interest: The author declares no conflict of interest.

\section{References}

1. Francis, I.R.; Chenevert, T.L.; Gubin, B.; Collomb, L.; Ensminger, W.; Walkerandrews, S.; Glazer, G.M. MALIGNANT HEPATIC-TUMORS - P-31 MR SPECTROSCOPY WITH ONE-DIMENSIONAL CHEMICAL-SHIFT IMAGING. Radiology 1991, 180, 341-344, doi:10.1148/radiology.180.2.1648755.

2. Jue, T.; Rothman, D.L.; Tavitian, B.A.; Shulman, R.G. Natural-abundance 13C NMR study of glycogen repletion in human liver and muscle. Proceedings. of. the. National. Academy. of. Sciences. of. the. United. States. of. America. 1989, $86,1439-1442$.

3. Rothman, D.L.; Magnusson, I.; Katz, L.D.; Shulman, R.G.; Shulman, G.I. QUANTITATION OF HEPATIC GLYCOGENOLYSIS AND GLUCONEOGENESIS IN FASTING HUMANS WITH C-13 NMR. Science 1991, 254, 573576, doi:10.1126/science.1948033.

4. Jue, T.; Rothman, D.L.; Lohman, J.A.; Hughes, E.W.; Hanstock, C.C.; Shulman, R.G. Surface coil localization of 31P NMR signals from orthotopic human kidney and liver. Proceedings. of. the. National. Academy. of. Sciences. of. the. United. States. of. America. 1988, 85, 971-974.

5. Fischbach, F.; Bruhn, H. Assessment of in vivo $1 \mathrm{H}$ magnetic resonance spectroscopy in the liver: A review. Liver International 2008, 28, 297-307, doi:10.1111/j.1478-3231.2007.01647.x. 
6. Xu, L.; Liu, B.; Huang, Y.; Liu, X.; Zhang, S.W.; Xin, X.G.; Zheng, J.Z. 3.0 T proton magnetic resonance spectroscopy of the liver: Quantification of choline. World Journal of Gastroenterology 2013, 19, 1472-1477, doi:10.3748/wjg.v19.i9.1472.

7. Fischbach, F.; Schirmer, T.; Thormann, M.; Freund, T.; Ricke, J.; Bruhn, H. Quantitative proton magnetic resonance spectroscopy of the normal liver and malignant hepatic lesions at 3.0 Tesla. European Radiology 2008, 18, 2549-2558, doi:10.1007/s00330-008-1040-8.

8. Munakata, T.; Griffiths, R.D.; Martin, P.A.; Jenkins, S.A.; Shields, R.; Edwards, R.H.T. AN INVIVO P-31 MRS STUDY OF PATIENTS WITH LIVER-CIRRHOSIS - PROGRESS TOWARDS A NONINVASIVE ASSESSMENT OF DISEASE SEVERITY. Nmr in Biomedicine 1993, 6, 168-172, doi:10.1002/nbm.1940060211.

9. Grant, A.; Metzger, G.J.; Van de Moortele, P.F.; Adriany, G.; Olman, C.; Zhang, L.; Koopermeiners, J.; Eryaman, Y.; Koeritzer, M.; Adams, M.E.; et al. 10.5 T MRI static field effects on human cognitive, vestibular, and physiological function. Magnetic Resonance Imaging 2020, 73, 163-176, doi:10.1016/j.mri.2020.08.004.

10. Budinger, T.F.; Bird, M.D.; Frydman, L.; Long, J.R.; Mareci, T.H.; Rooney, W.D.; Rosen, B.; Schenck, J.F.; Schepkin, V.D.; Sherry, A.D.; et al. Toward $20 \mathrm{~T}$ magnetic resonance for human brain studies: opportunities for discovery and neuroscience rationale. Magnetic Resonance Materials in Physics Biology and Medicine 2016, 29, 617-639, doi:10.1007/s10334-016-0561-4.

11. Ladd, M.E.; Bachert, P.; Meyerspeer, M.; Moser, E.; Nagel, A.M.; Norris, D.G.; Schmitter, S.; Speck, O.; Straub, S.; Zaiss, M. Pros and cons of ultra-high-field MRI/MRS for human application. Progress in Nuclear Magnetic Resonance Spectroscopy 2018, 109, 1-50, doi:10.1016/j.pnmrs.2018.06.001.

12. Lopez-Kolkovsky, A.L.; Meriaux, S.; Boumezbeur, F. Metabolite and Macromolecule T-1 and T-2 Relaxation Times in the Rat Brain in vivo at 17.2T. Magnetic Resonance in Medicine 2016, 75, 503-514, doi:10.1002/mrm.25602.

13. Pollack, M.H.; Jensen, J.E.; Simon, N.M.; Kaufinan, R.E.; Renshaw, P.F. High-field MRS study of GABA, glutamate and glutamine in social anxiety disorder: Response to treatment with levetiracetam. Progress in Neuro-Psychopharmacology $\mathcal{E}$ Biological Psychiatry 2008, 32, 739-743, doi:10.1016/j.pnpbp.2007.11.023.

14. Deelchand, D.K.; Ugurbil, K.; Henry, P.G. Investigating brain metabolism at high fields using localized C-13 NMR spectroscopy without H-1 decoupling. Magnetic Resonance in Medicine 2006, 55, 279-286.

15. Rivera, D.; Kalleveen, I.; de Castro, C.A.; van Laarhoven, H.; Klom, D.; van Der Kemp, W.; Stoker, J.; Nederveen, A. Inherently decoupled H-1 antennas and P-31 loops for metabolic imaging of liver metastasis at 7 T. Nmr in Biomedicine 2020, 33, doi:e4221

10.1002/nbm.4221.

16. van Houtum, Q.; Welting, D.; Gosselink, W.J.M.; Klomp, D.W.J.; de Castro, C.S.A.; van der Kemp, W.J.M. Low SAR P31 (multi-echo) spectroscopic imaging using an integrated whole-body transmit coil at 7T. Nmr in Biomedicine 2019, 32, doi:e4178

10.1002/nbm.4178.

17. van Gorp, J.S.; Seevinck, P.R.; Andreychenko, A.; Raaijmakers, A.J.E.; Luijten, P.R.; Viergever, M.A.; Koopman, M.; Boer, V.O.; Klomp, D.W.J. F-19 MRSI of capecitabine in the liver at $7 \mathrm{~T}$ using broadband transmit-receive antennas and dualband RF pulses. Nmr in Biomedicine 2015, 28, 1433-1442, doi:10.1002/nbm.3390.

18. Szczepaniak, L.S.; Nurenberg, P.; Leonard, D.; Browning, J.D.; Reingold, J.S.; Grundy, S.; Hobbs, H.H.; Dobbins, R.L. Magnetic resonance spectroscopy to measure hepatic triglyceride content: prevalence of hepatic steatosis in the general population. American Journal of Physiology-Endocrinology and Metabolism 2005, 288, E462-E468, doi:10.1152/ajpendo.00064.2004.

19. Di Martino, M.; Pacifico, L.; Bezzi, M.; Di Miscio, R.; Sacconi, B.; Chiesa, C.; Catalano, C. Comparison of magnetic resonance spectroscopy, proton density fat fraction and histological analysis in the quantification of liver steatosis in children and adolescents. World Journal of Gastroenterology 2016, 22, 8812-8819, doi:10.3748/wjg.v22.i39.8812. 
20. Caussy, C.; Reeder, S.B.; Sirlin, C.B.; Loomba, R. Noninvasive, Quantitative Assessment of Liver Fat by MRI-PDFF as an Endpoint in NASH Trials. Hepatology 2018, 68, 763-772, doi:10.1002/hep.29797.

21. Caussy, C.; Alquiraish, M.H.; Nguyen, P.; Hernandez, C.; Cepin, S.; Fortney, L.E.; Ajmera, V.; Bettencourt, R.; Collier, S.; Hooker, J.; et al. Optimal threshold of controlled attenuation parameter with MRI-PDFF as the gold standard for the detection of hepatic steatosis. Hepatology 2018, 67, 1348-1359, doi:10.1002/hep.29639.

22. Soares, A.F.; Lei, H.X.; Gruetter, R. Characterization of hepatic fatty acids in mice with reduced liver fat by ultra-short echo time H-1-MRS at 14.1 T in vivo. Nmr in Biomedicine 2015, 28, 1009-1020, doi:10.1002/nbm.3345.

23. Ramamonjisoa, N.; Ratiney, H.; Mutel, E.; Guillou, H.; Mithieux, G.; Pilleul, F.; Rajas, F.; Beuf, O.; Cavassila, S. In vivo hepatic lipid quantification using MRS at 7 Tesla in a mouse model of glycogen storage disease type 1a. Journal of Lipid Research 2013, 54, 2010-2022, doi:10.1194/j1r.D033399.

24. Weis, J.; Kullberg, J.; Ahlstrom, H. Multiple Breath-Hold Proton Spectroscopy of Human Liver at 3T: Relaxation Times and Concentrations of Glycogen, Choline, and Lipids. Journal of Magnetic Resonance Imaging 2018, 47, 410-417, doi:10.1002/jmri.25734.

25. Ouwerkerk, R.; Pettigrew, R.I.; Gharib, A.M. Liver Metabolite Concentrations Measured with H-1 MR Spectroscopy. Radiology 2012, 265, 565-575, doi:10.1148/radiol.12112344.

26. ter Voert, E.; Heijmen, L.; van Asten, J.J.A.; Wright, A.J.; Nagtegaal, I.D.; Punt, C.J.A.; de Wilt, J.H.W.; van Laarhoven, H.W.M.; Heerschap, A. Levels of choline-containing compounds in normal liver and liver metastases of colorectal cancer as recorded by H-1 MRS. Nmr in Biomedicine 2019, 32, doi:e4035

10.1002/nbm.4035.

27. Chen, W.; Avison, M.J.; Zhu, X.H.; Shulman, R.G. NMR-STUDIES OF H-1 NOES IN GLYCOGEN. Biochemistry 1993, 32, 11483-11487, doi:10.1021/bi00094a003.

28. Zhou, Y.; van Zijl, P.C.M.; Xu, X.; Xu, J.D.; Li, Y.G.; Chen, L.; Yadav, N.N. Magnetic resonance imaging of glycogen using its magnetic coupling with water. Proceedings of the National Academy of Sciences of the United States of America 2020, 117, 3144-3149, doi:10.1073/pnas.1909921117.

29. Bowers, J.L.; Lanir, A.; Metz, K.R.; Kruskal, J.B.; Lee, R.G.L.; Balschi, J.; Federman, M.; Khettry, U.; Clouse, M.E. NA-23NMR AND 31P-NMR STUDIES OF PERFUSED MOUSE-LIVER DURING NITROGEN HYPOXIA. American Journal of Physiology 1992, 262, G636-G644.

30. Kitai, T.; Tanaka, A.; Terasaki, M.; Okamoto, R.; Ozawa, K.; Morikawa, S.; Inubushi, T. ENERGY-METABOLISM OF THE LIVER IN BRAIN-DEAD DOGS ASSESSED BY P-31-NMR SPECTROSCOPY AND ARTERIAL KETONE-BODY RATIO. Life Sciences 1991, 49, 511-518, doi:10.1016/0024-3205(91)90068-m.

31. Buchli, R.; Meier, D.; Martin, E.; Boesiger, P. ASSESSMENT OF ABSOLUTE METABOLITE CONCENTRATIONS IN HUMAN TISSUE BY P-31 MRS IN-VIVO .2. MUSCLE, LIVER, KIDNEY. Magnetic Resonance in Medicine 1994, 32, 453458, doi:10.1002/mrm.1910320405.

Traussnigg, S.; Kienbacher, C.; Gajdosik, M.; Valkovic, L.; Halilbasic, E.; Stift, J.; Rechling, C.; Hofer, H.; Steindl-Munda, P.; Ferenci, P.; et al. Ultra-high-field magnetic resonance spectroscopy in non-alcoholic fatty liver disease: Novel mechanistic and diagnostic insights of energy metabolism in non-alcoholic steatohepatitis and advanced fibrosis. Liver International 2017, 37, 1544-1553, doi:10.1111/liv.13451.

33. Buehler, T.; Kreis, R.; Boesch, C. Comparison of 31P saturation and inversion magnetization transfer in human liver and skeletal muscle using a clinical MR system and surface coils. Nmr in Biomedicine 2015, 28, 188-199, doi:10.1002/nbm.3242.

34. Campbell, S.L.; Jones, K.A.; Shulman, R.G. In vivo 31P nuclear magnetic resonance saturation transfer measurements of phosphate exchange reactions in the yeast Saccharomyces cerevisiae. FEBS. Letters. 1985, 193, 189-193. 
35. Alger, J.R.; den, H.J.A.; Shulman, R.G. In vivo phosphorus-31 nuclear magnetic resonance saturation transfer studies of adenosinetriphosphatase kinetics in Saccharomyces cerevisiae. Biochemistry. 1982, 21, 2957-2963.

36. Bernardo-Seisdedos, G.; Bilbao, J.; Fernandez-Ramos, D.; Lopitz-Otsoa, F.; de Juan, V.G.; Bizkarguenaga, M.; Mateos, B.; Fondevila, M.F.; Abril-Fornaguera, J.; Diercks, T.; et al. Metabolic Landscape of the Mouse Liver by Quantitative P-31 Nuclear Magnetic Resonance Analysis of the Phosphorome. Hepatology, doi:10.1002/hep.31676.

Chmelik, M.; Povazan, M.; Krssak, M.; Gruber, S.; Tkacov, M.; Trattnig, S.; Bogner, W. In vivo 31P magnetic resonance spectroscopy of the human liver at $7 \mathrm{~T}$ : an initial experience. Nmr in Biomedicine 2014, 27, 478-485, doi:10.1002/nbm.3084.

Purvis, L.A.B.; Clarke, W.T.; Valkovic, L.; Levick, C.; Pavlides, M.; Barnes, E.; Cobbold, J.F.; Robson, M.D.; Rodgers, C.T. Phosphodiester content measured in human liver by in vivo P-31 MR spectroscopy at 7 tesla. Magnetic Resonance in Medicine 2017, 78, 2095-2105, doi:10.1002/mrm.26635.

39. Valkovic, L.; Chmelik, M.; Krssak, M. In-vivo P-31-MRS of skeletal muscle and liver: A way for non-invasive assessment of their metabolism. Analytical Biochemistry 2017, 529, 193-215, doi:10.1016/j.ab.2017.01.018.

40.

Bierwagen, A.; Begovatz, P.; Nowotny, P.; Markgraf, D.; Nowotny, B.; Koliaki, C.; Giani, G.; Klueppelholz, B.; Lundbom, J.; Roden, M. Characterization of the peak at 2.06ppm in P-31 magnetic resonance spectroscopy of human liver: phosphoenolpyruvate or phosphatidylcholine? Nmr in Biomedicine 2015, 28, 898-905, doi:10.1002/nbm.3323.

Kupriyanova, Y.; Zaharia, O.P.; Bobrov, P.; Karusheva, Y.; Burkart, V.; Szendroedi, J.; Hwang, J.-H.; Roden, M.; Grp, G.D.S. Early changes in hepatic energy metabolism and lipid content in recent-onset type 1 and 2 diabetes mellitus. Journal of Hepatology 2021, 74, 1028-1037, doi:10.1016/j.jhep.2020.11.030.

Pfleger, L.; Gajdosik, M.; Wolf, P.; Smajis, S.; Fellinger, P.; Kuehne, A.; Krumpolec, P.; Trattnig, S.; Winhofer, Y.; Krebs, M.; et al. Absolute Quantification of Phosphor-Containing Metabolites in the Liver Using P-31 MRSI and Hepatic Lipid Volume Correction at 7T Suggests No Dependence on Body Mass Index or Age. Journal of Magnetic Resonance Imaging 2019, 49, 597-607, doi:10.1002/jmri.26225.

Hakkarainen, A.; Lundbom, J.; Tuominen, E.K.; Taskinen, M.-R.; Pietilainen, K.H.; Lundbom, N. Measuring short-term liver metabolism non-invasively: postprandial and post-exercise H-1 and P-31 MR spectroscopy. Magnetic Resonance Materials in Physics Biology and Medicine 2015, 28, 57-66, doi:10.1007/s10334-014-0450-7.

Bawden, S.J.; Stephenson, M.C.; Ciampi, E.; Hunter, K.; Marciani, L.; Macdonald, I.A.; Aithal, G.P.; Morris, P.G.; Gowland, P.A. Investigating the effects of an oral fructose challenge on hepatic ATP reserves in healthy volunteers: A P-31 MRS study. Clinical Nutrition 2016, 35, 645-649, doi:10.1016/j.clnu.2015.04.001.

Boesch, C.; Elsing, C.; Wegmuller, H.; Felblinger, J.; Vock, P.; Reichen, J. Effect of ethanol and fructose on liver metabolism: A dynamic (31)phosphorus magnetic resonance spectroscopy study in normal volunteers. Magnetic Resonance Imaging 1997, 15, 1067-1077, doi:10.1016/s0730-725x(97)00163-x.

Changani, K.K.; Jalan, R.; Cox, I.J.; Ala-Korpela, M.; Bhakoo, K.; Taylor-Robinson, S.D.; Bell, J.D. Evidence for altered hepatic gluconeogenesis in patients with cirrhosis using in vivo 31-phosphorus magnetic resonance spectroscopy. Gut 2001, 49, 557-564, doi:10.1136/gut.49.4.557.

Chu, W.C.W.; Lam, W.W.M.; Lee, K.H.; Yeung, D.K.W.; Sihoe, J.; Yeung, C.K. Phosphorus-31 MR spectroscopy in pediatric liver transplant recipients: A noninvasive assessment of graft status with correlation with liver function tests and liver biopsy. American Journal of Roentgenology 2005, 184, 1624-1629, doi:10.2214/ajr.184.5.01841624.

48. Leij-Halfwerk, S.; Agteresch, H.J.; Sijens, P.E.; Dagnelie, P.C. Adenosine triphosphate infusion increases liver energy status in advanced lung cancer patients: An in vivo P-31 magnetic resonance spectroscopy study. Hepatology 2002, 35, 421-424, doi:10.1053/jhep.2002.31318.

49. Petersen, K.F.; West, A.B.; Reuben, A.; Rothman, D.L.; Schulman, G.I. Noninvasive assessment of hepatic triglyceride content in humans with C-13 nuclear magnetic resonance spectroscopy. Hepatology 1996, 24, 114-117, doi:10.1002/hep.510240119. 
50. Stender, S.; Zaha, V.G.; Malloy, C.R.; Sudderth, J.; DeBerardinis, R.J.; Park, J.M. Assessment of Rapid Hepatic Glycogen Synthesis in Humans Using Dynamic C-13 Magnetic Resonance Spectroscopy. Hepatology Communications 2020, 4, 425433, doi:10.1002/hep4.1458.

51. Skamarauskas, J.T.; Oakley, F.; Smith, F.E.; Bawn, C.; Dunn, M.; Vidler, D.S.; Clemence, M.; Blain, P.G.; Taylor, R.; Gamcsik, M.P.; et al. Noninvasive In Vivo Magnetic Resonance Measures of Glutathione Synthesis in Human and Rat Liver as an Oxidative Stress Biomarker. Hepatology 2014, 59, 2321-2330, doi:10.1002/hep.26925.

52. Petersen, K.F.; Cline, G.W.; Gerard, D.P.; Magnusson, I.; Rothman, D.L.; Shulman, G.I. Contribution of net hepatic glycogen synthesis to disposal of an oral glucose load in humans. Metabolism-Clinical and Experimental 2001, 50, 598601.

53. Befroy, D.E.; Perry, R.J.; Jain, N.; Dufour, S.; Cline, G.W.; Trimmer, J.K.; Brosnan, J.; Rothman, D.L.; Petersen, K.F.; Shulman, G.I. Direct assessment of hepatic mitochondrial oxidative and anaplerotic fluxes in humans using dynamic $C$ 13 magnetic resonance spectroscopy. Nature Medicine 2014, 20, 98-+, doi:10.1038/nm.3415.

54. Lindeboom, L.; de Graaf, R.A.; Nabuurs, C.I.; van Ewijk, P.A.; Hesselink, M.K.C.; Wildberger, J.E.; Schrauwen, P.; Schrauwen-Hinderling, V.B. Quantum coherence spectroscopy to measure dietary fat retention in the liver. Jci Insight 2016, 1, doi:e84671

10.1172/jci.insight.84671.

55. de Graaf, R.A. Theoretical and experimental evaluation of broadband decoupling techniques for in vivo nuclear magnetic resonance spectroscopy. Magnetic Resonance in Medicine 2005, 53, 1297-1306, doi:10.1002/mrm.20507.

56. Rothman, D.L.; Magnusson, I.; Katz, L.D.; Shulman, R.G.; Shulman, G.I. Quantitation of hepatic glycogenolysis and gluconeogenesis in fasting humans with 13C NMR. Science. 1991, 254, 573-576.

57. Veeraiah, P.; Brouwers, K.; Wildberger, J.E.; Schrauwen-Hinderling, V.B.; Lindeboom, L. Application of a BIlinear Rotation Decoupling (BIRD) filter in combination with J-difference editing for indirect(13)C measurements in the human liver. Magnetic Resonance in Medicine 2020, 84, 2911-2917, doi:10.1002/mrm.28394.

58. Wang, Z.J.; Ohliger, M.A.; Larson, P.E.Z.; Gordon, J.W.; Bok, R.A.; Slater, J.; Villanueva-Meyer, J.E.; Hess, C.P.; Kurhanewicz, J.; Vigneron, D.B. Hyperpolarized C-13 MRI: State of the Art and Future Directions. Radiology 2019, 291, 273-284, doi:10.1148/radiol.2019182391.

59. Kurhanewicz, J.; Vigneron, D.B.; Ardenkjaer-Larsen, J.H.; Bankson, J.A.; Brindle, K.; Cunningham, C.H.; Gallagher, F.A.; Keshari, K.R.; Kjaer, A.; Laustsen, C.; et al. Hyperpolarized C-13 MRI: Path to Clinical Translation in Oncology. Neoplasia 2019, 21, 1-16, doi:10.1016/j.neo.2018.09.006.

60. De Feyter, H.M.; Thomas, M.A.; Behar, K.L.; de Graaf, R.A. NMR visibility of deuterium-labeled liver glycogen in vivo. Magnetic Resonance in Medicine 2021, doi:10.1002/mrm.28717.

61. De Feyter, H.M.; Behar, K.L.; Corbin, Z.A.; Fulbright, R.K.; Brown, P.B.; McIntyre, S.; Nixon, T.W.; Rothman, D.L.; de Graaf, R.A. Deuterium metabolic imaging (DMI) for MRI-based 3D mapping of metabolism in vivo. Science Advances 2018, 4, doi:eaat7314

10.1126/sciadv.aat7314.

62.

Rose, I.A.; Oconnell, E.L. INTRAMOLECULAR HYDROGEN TRANSFER IN PHOSPHOGLUCOSE ISOMERASE REACTION. Journal of Biological Chemistry 1961, 236, 3086-\&.

63. Wolf, W.; Albright, M.J.; Silver, M.S.; Weber, H.; Reichardt, U.; Sauer, R. F-19 NMR SPECTROSCOPIC STUDIES OF THE METABOLISM OF 5-FLUOROURACIL IN THE LIVER OF PATIENTS UNDERGOING CHEMOTHERAPY. Magnetic Resonance Imaging 1987, 5, 165-169, doi:10.1016/0730-725x(87)90016-6.

64. Peters, G.J.; Lankelma, J.; Kok, R.M.; Noordhuis, P.; Vangroeningen, C.J.; Vanderwilt, C.L.; Meyer, S.; Pinedo, H.M. PROLONGED RETENTION OF HIGH-CONCENTRATIONS OF 5-FLUOROURACIL IN HUMAN AND MURINE 
TUMORS AS COMPARED WITH PLASMA. Cancer Chemotherapy and Pharmacology 1993, 31, 269-276, doi:10.1007/bf00685670.

65. Li, C.W.; Gonen, O. Simultaneous 3D NMR spectroscopy of fluorine and phosphorus in human liver during 5fluorouracil chemotherapy. Magnetic Resonance in Medicine 1996, 35, 841-847, doi:10.1002/mrm.1910350609.

66. MurphyBoesch, J.; Li, C.W.; He, L.B.; PadavicShaller, K.A.; Negendank, W.; Brown, T.R. Proton-decoupled F-19 spectroscopy of 5-FU catabolites in human liver. Magnetic Resonance in Medicine 1997, 37, 321-326, doi:10.1002/mrm.1910370302.

67. Wolf, W.; Waluch, V.; Presant, C.A. Non-invasive F-19-NMRS of 5-fluorouracil in pharmacokinetics and pharmacodynamic studies. Nmr in Biomedicine 1998, 11, 380-387, doi:10.1002/(sici)1099-1492(1998110)11:7<380::aidnbm517>3.0.co;2-q.

68. Mohankrishnan, P.; Hutchins, L.; Nauke, S.; Sprigg, J.; Cardwell, D.; Williamson, M.R.; Komoroski, R.A.; Jagannathan, N.R. Metabolism of 5-fluorouracil in human liver: An in vivo F-19 NMR study. Current Science 1999, 76, 677-680.

69. Schlemmer, H.P.; Bachert, P.; Semmler, W.; Hohenberger, P.; Schlag, P.; Lorenz, W.J.; Vankaick, G. DRUGMONITORING OF 5-FLUOROURACIL - IN-VIVO F-19 NMR-STUDY DURING 5-FU CHEMOTHERAPY IN PATIENTS WITH METASTASES OF COLORECTAL ADENOCARCINOMA. Magnetic Resonance Imaging 1994, 12, 497-511, doi:10.1016/0730-725x(94)92544-5.

70. Findlay, M.P.N.; Leach, M.O.; Cunningham, D.; Collins, D.J.; Payne, G.S.; Glaholm, J.; Mansi, J.L.; McCready, V.R. THE NONINVASIVE MONITORING OF LOW-DOSE, INFUSIONAL 5-FLUOROURACIL AND ITS MODULATION BY INTERFERON-ALPHA USING IN-VIVO F-19 MAGNETIC-RESONANCE SPECTROSCOPY IN PATIENTS WITH COLORECTAL-CANCER - A PILOT-STUDY. Annals of Oncology 1993, 4, 597-602, doi:10.1093/oxfordjournals.annonc.a058595.

Harada, M.; Nishitani, H.; Koga, K.; Miura, I.; Kimura, A. COMPARATIVE-STUDIES ON THE METABOLISM OF NEW FLUORINATED PYRIMIDINE DRUGS IN THE LIVER BY INVIVO F-19 MAGNETIC-RESONANCE SPECTROSCOPIC OBSERVATION. Japanese Journal of Cancer Research 1993, 84, 197-202, doi:10.1111/j.13497006.1993.tb02855.x.

Klomp, D.; van Laarhoven, H.; Scheenen, T.; Kamm, Y.; Heerschap, A. Quantitative F-19 MR spectroscopy at 3 T to detect heterogeneous capecitabine metabolism in human liver. Nmr in Biomedicine 2007, 20, 485-492, doi:10.1002/nbm.1111.

Payne, G.S.; Collins, D.J.; Loynds, P.; Mould, G.; Murphy, P.S.; Dzik-Jurasz, A.S.K.; Kessar, P.; Haque, N.; Yamaguchi, M.; Atarashi, S.; et al. Quantitative assessment of the hepatic pharmacokinetics of the antimicrobial sitafloxacin in humans using in vivo F-19 magnetic resonance spectroscopy. British Journal of Clinical Pharmacology 2005, 59, 244-248, doi:10.1111/j.1365-2125.2004.02246.x.

74. Bilecen, D.; Schulte, A.C.; Kaspar, A.; Kustermann, E.; Seelig, J.; von Elverfeldt, D.; Scheffler, K. Detection of the nonsteroidal anti-inflammatory drug niflumic acid in humans: a combined F-19-MRS in vivo and in vitro study. Nmr in Biomedicine 2003, 16, 144-151, doi:10.1002/nbm.820.

75. Merritt, M.E.; Harrison, C.; Sherry, A.D.; Malloy, C.R.; Burgess, S.C. Flux through hepatic pyruvate carboxylase and phosphoenolpyruvate carboxykinase detected by hyperpolarized C-13 magnetic resonance. Proceedings of the National Academy of Sciences of the United States of America 2011, 108, 19084-19089, doi:10.1073/pnas.1111247108.

76. Marco-Rius, I.; Wright, A.J.; Hu, D.E.; Savic, D.; Miller, J.J.; Timm, K.N.; Tyler, D.; Brindle, K.M.; Comment, A. Probing hepatic metabolism of 2-C-13 dihydroxyacetone in vivo with(1)H-decoupled hyperpolarized(13)C-MR. Magnetic Resonance Materials in Physics Biology and Medicine 2021, 34, 49-56, doi:10.1007/s10334-020-00884-y. 
78. Ragavan, M.; McLeod, M.A.; Giacalone, A.G.; Merritt, M.E. Hyperpolarized Dihydroxyacetone Is a Sensitive Probe of Hepatic Gluconeogenic State. Metabolites 2021, 11, doi:441

10.3390/metabo11070441.

79. Chen, J.; Hackett, E.P.; Kovacs, Z.; Malloy, C.R.; Park, J.M. Assessment of hepatic pyruvate carboxylase activity using hyperpolarized 1-C-13 -1-lactate. Magnetic Resonance in Medicine 2020, doi:10.1002/mrm.28489.

80. Moreno, K.X.; Harrison, C.E.; Merritt, M.E.; Kovacs, Z.; Malloy, C.R.; Sherry, A.D. Hyperpolarized delta- 1-C-13 gluconolactone as a probe of the pentose phosphate pathway. Nmr in Biomedicine 2017, 30, doi:e3713

10.1002/nbm.3713.

81. Hoyer, K.F.; Laustsen, C.; Ringgaard, S.; Qi, H.; Mariager, C.O.; Nielsen, T.S.; Sundekilde, U.K.; Treebak, J.T.; Jessen, N.; Stodkilde-Jorgensen, H. Assessment of mouse liver 1-C-13 pyruvate metabolism by dynamic hyperpolarized MRS. Journal of Endocrinology 2019, 242, 251-260, doi:10.1530/joe-19-0159.

82. von Morze, C.; Allu, P.K.R.; Chang, G.Y.; Marco-Rius, I.; Milshteyn, E.; Wang, Z.J.; Ohliger, M.A.; Gleason, C.E.; Kurhanewicz, J.; Vigneron, D.B.; et al. Non-invasive detection of divergent metabolic signals in insulin deficiency vs. insulin resistance in vivo. Scientific Reports 2018, 8, doi:2088

10.1038/s41598-018-20264-w.

83. Maptue, N.; Jiang, W.; Harrison, C.; Funk, A.M.; Sharma, G.; Malloy, C.R.; Sherry, D.; Khemtong, C. Esterase-Catalyzed Production of Hyperpolarized C-13-Enriched Carbon Dioxide in Tissues for Measuring pH. Acs Sensors 2018, 3, 22322236, doi:10.1021/acssensors.8b01097.

84. Wibowo, A.; Park, J.M.; Liu, S.-C.; Khosla, C.; Spielman, D.M. Real-Time in Vivo Detection of H2O2 Using Hyperpolarized C-13-Thiourea. Acs Chemical Biology 2017, 12, 1737-1742, doi:10.1021/acschembio.7b00130.

85. Park, J.M.; Khemtong, C.; Liu, S.-C.; Hurd, R.E.; Spielman, D.M. In vivo assessment of intracellular redox state in rat liver using hyperpolarized 1-C-13 Alanine. Magnetic Resonance in Medicine 2017, 77, 1741-1748, doi:10.1002/mrm.26662.

86. von Morze, C.; Engelbach, J.A.; Reed, G.D.; Chen, A.P.; Quirk, J.D.; Blazey, T.; Mahar, R.; Malloy, C.R.; Garbow, J.R.; Merritt, M.E. N-15-carnitine, a novel endogenous hyperpolarized MRI probe with long signal lifetime. Magnetic Resonance in Medicine 2021, 85, 1814-1820, doi:10.1002/mrm.28578.

87. Jensen, P.R.; Serra, S.C.; Miragoli, L.; Karlsson, M.; Cabella, C.; Poggi, L.; Venturi, L.; Tedoldi, F.; Lerche, M.H. Hyperpolarized 1,3-C-13(2) ethyl acetoacetate is a novel diagnostic metabolic marker of liver cancer. International Journal of Cancer 2015, 136, E117-E126, doi:10.1002/ijc.29162.

88. Perkons, N.R.; Kiefer, R.M.; Noji, M.C.; Pourfathi, M.; Ackerman, D.; Siddiqui, S.; Tischfield, D.; Profka, E.; Johnson, O.; Pickup, S.; et al. Hyperpolarized Metabolic Imaging Detects Latent Hepatocellular Carcinoma Domains Surviving Locoregional Therapy. Hepatology 2020, 72, 140-154, doi:10.1002/hep.30970.

89. Rardin, M.J.; He, W.; Nishida, Y.; Newman, J.C.; Carrico, C.; Danielson, S.R.; Guo, A.; Gut, P.; Sahu, A.K.; Li, B.; et al. SIRT5 Regulates the Mitochondrial Lysine Succinylome and Metabolic Networks. Cell metabolism 2013, 18, 920-933, doi:10.1016/j.cmet.2013.11.013.

90. Indiveri, C.; Iacobazzi, V.; Tonazzi, A.; Giangregorio, N.; Infantino, V.; Convertini, P.; Console, L.; Palmieri, F. The mitochondrial carnitine/acylcarnitine carrier: Function, structure and physiopathology. Molecular Aspects of Medicine 2011, 32, 223-233, doi:10.1016/j.mam.2011.10.008.

91. Wanders, R.J.A.; Vreken, P.; den Boer, M.E.J.; Wijburg, F.A.; van Gennip, A.H.; Ijlst, L. Disorders of mitochondrial fatty acyl-CoA beta-oxidation. J. Inherit. Metab. Dis. 1999, 22, 442-487, doi:10.1023/a:1005504223140. 
92. Bray, F.; Ferlay, J.; Soerjomataram, I.; Siegel, R.L.; Torre, L.A.; Jemal, A. Global cancer statistics 2018: GLOBOCAN estimates of incidence and mortality worldwide for 36 cancers in 185 countries (vol 68, pg 394, 2018). Ca-a Cancer Journal for Clinicians 2020, 70, 313-313, doi:10.3322/caac.21609.

93. Paik, J.M.; Golabi, P.; Younossi, Y.; Mishra, A.; Younossi, Z.M. Changes in the Global Burden of Chronic Liver Diseases From 2012 to 2017: The Growing Impact of NAFLD. Hepatology 2020, 72, 1605-1616, doi:10.1002/hep.31173. 